\title{
Inhibition of carbachol-induced inositol phosphate accumulation in the embryonic retina promoted by kainate and veratridine
}

G. Sanches and A.L.M. Ventura

\author{
Departamento de Neurobiologia, Universidade Federal Fluminense, Niterói, RJ, Brasil
}

\section{Correspondence \\ A.L.M. Ventura \\ Departamento de Neurobiologia \\ Universidade Federal Fluminense \\ Caixa Postal 100180 \\ 24001-970 Niterói, RJ \\ Brasil \\ Fax: 55 (021) 719-5934 \\ E-mail: almv@ax.ibase.org.br. \\ Research supported by $\mathrm{CNPq}$, Pró-Reitoria de Pesquisa e Pós-Graduação-UFF (PRO PP-UFF), FAPERJ and FINEP. G. Sanches is the recipient of a FAPERJ fellowship.}

Received December 16, 1997 Accepted April 14, 1998

\begin{abstract}
In the present study, we report that low concentrations of the glutamate ionotropic agonist kainate decreased the turnover of $\left[{ }^{3} \mathrm{H}\right]-$ phosphoinositides $\left(\left[{ }^{3} \mathrm{H}\right]\right.$-InsPs $)$ induced by muscarinic receptors in the chick embryonic retina. When $100 \mu \mathrm{M}$ carbachol was used, the estimated $\mathrm{IC}_{50}$ value for kainate was $0.2 \mu \mathrm{M}$ and the maximal inhibition of $\sim 50 \%$ was obtained with $1 \mu \mathrm{M}$ or higher concentrations of the glutamatergic agonist. Our data also show that veratridine, a neurotoxin that increases the permeability of voltage-sensitive sodium channels, had no effect on [ $\left.{ }^{3} \mathrm{H}\right]$-InsPs levels of the embryonic retina. However, $50 \mu \mathrm{M}$ veratridine, but not $50 \mathrm{mM} \mathrm{KCl}$, inhibited $\sim 65 \%$ of the retinal response to carbachol. While carbachol increased $\left[{ }^{3} \mathrm{H}\right]-$ InsPs levels from $241.2 \pm 38.0$ to $2044.5 \pm 299.9 \mathrm{cpm} / \mathrm{mg}$ protein, retinal response decreased to $861.6 \pm 113.9 \mathrm{cpm} / \mathrm{mg}$ protein when tissues were incubated with carbachol plus veratridine. These results suggest that the accumulation of phosphoinositides induced by activation of muscarinic receptors can be inhibited by the influx of $\mathrm{Na}^{+}$ions triggered by activation of kainate receptors or opening of voltagesensitive sodium channels in the chick embryonic retina.
\end{abstract}

Key words

- Muscarinic receptors

- Phosphoinositides

- Kainate

- Sodium channels

- Retina
An extensive amount of data has shown the existence of G-protein-linked receptors negatively coupled to adenylate cyclase and ion channels. However, no inhibitory Gproteins capable of interfering with the phospholipase $\mathrm{C}$ transduction pathway have been described so far. Despite the lack of such protein(s), several mechanisms have been proposed to mediate the inhibition of the phosphoinositide (InsPs) turnover pathway (1). They include receptor desensitization and/or sequestration, depletion of intracellular calcium stores, desensitization of inosi- tol-trisphosphate receptors, substrate depletion and product inhibition.

The development of the [ $\left.{ }^{3} \mathrm{H}\right]$-phosphoinositide $\left(\left[{ }^{3} \mathrm{H}\right]\right.$-InsPs) turnover induced by muscarinic receptors in the chick embryo retina was characterized previously (2). The response of the retina to carbachol was high in early developing tissues and decreased after synaptogenesis. Moreover, both the mobilization of intracellular calcium by muscarinic receptors (3) and capacitive influx of this ion (4) were shown to be high in early developing chick retinas, also decreasing after 
the synaptogenesis of this tissue. These observations, together with data showing that phospholipase $\mathrm{C}$ inhibitors decrease calcium mobilization induced by muscarinic receptors in developing chick retina (5) and that biochemical properties of these receptors change during chick retinal development (68 ), reinforce the idea of the existence of an embryonic muscarinic receptor system in this tissue (3).

Glutamate is also a well-recognized neurotransmitter in the vertebrate retina. In the chick embryo retina, this compound was shown to decrease the retinal accumulation of $\left[{ }^{3} \mathrm{H}\right]$-InsPs induced by the activation of muscarinic receptors through NMDA and kainate receptors. No such inhibitory effect was observed with GABA, dopamine, adenosine or glycine (2).

In the present study, we further characterized the regulation of the turnover of $\left[{ }^{3} \mathrm{H}\right]$ phosphoinositides induced by muscarinic receptors in the chick embryonic retina by examining the potency of kainate to decrease the retinal response to carbachol. We also examined the effects of veratridine and high extracellular $\mathrm{KCl}$, two depolarizing agents known to increase the influx of $\mathrm{Na}^{+}$ions into neuronal cells.

Figure 1 - Effect of increasing concentrations of kainate on the carbachol-induced $\left[{ }^{3} \mathrm{H}\right]-$ InsPs accumulation in retinas of 14-dayold embryos (E14). Retinas were incubated with $100 \mu \mathrm{M}$ carbachol in the absence or presence of the indicated concentrations of kainate. Basal levels: $374.6 \pm$ $41.3 \mathrm{cpm} / \mathrm{mg}$ protein. Each point represents the mean \pm SEM (error bars) for 2 to 4 separate experiments ( $N=4$ to 8 retinas from different embryos).

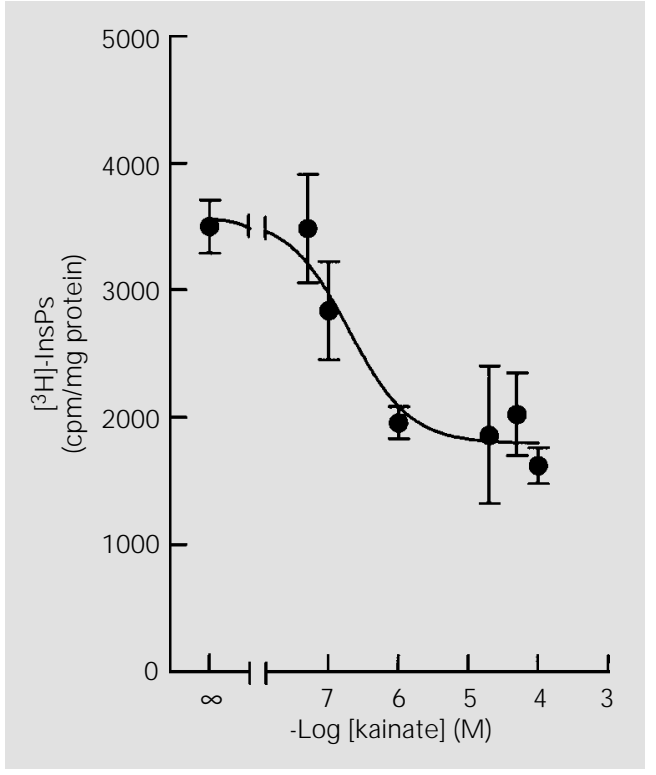

The embryos were decapitated, the eyes removed and the retinas dissected out free of the pigmented epithelium in cold calciumand magnesium-free medium (CMF) containing $131 \mathrm{mM} \mathrm{NaCl}, 4.09 \mathrm{mM} \mathrm{KCl}, 0.45$ $\mathrm{mM} \mathrm{KH}_{2} \mathrm{PO}_{4}, 0.92 \mathrm{mM} \mathrm{Na}_{2} \mathrm{HPO}_{4}, 12.2 \mathrm{mM}$ glucose and $9.4 \mathrm{mM} \mathrm{NaHCO}_{3}, \mathrm{pH}$ 7.3.

Retinas were incubated for $2.5 \mathrm{~h}$, at $37^{\circ} \mathrm{C}$, in $1 \mathrm{ml}$ of inositol-free Dulbecco's modified Eagle's medium (DMEM; Life Technologies, Grand Island, NY), previously oxygenated and containing $1 \mu \mathrm{Ci}\left[{ }^{3} \mathrm{H}\right]$-myo-inositol. $\mathrm{LiCl}$, to a final concentration of $10 \mathrm{mM}$, was added $1.5 \mathrm{~h}$ after the beginning of incubation. Carbachol was added and the tissues were incubated for an additional 1-h period. Incubations were interrupted by washing the tissues three times with $2 \mathrm{ml}$ of Hank's balanced salt solution and by the addition of trichloroacetic acid (final concentration, $15 \%)$.

The protein present in the samples was removed by centrifugation at $27,000 \mathrm{~g}$ for 30 min, dissolved in $1 \mathrm{~N} \mathrm{NaOH}$ and quantified as described (9). The aqueous phase was washed three times with ether and neutralized with an equal volume of $20 \mathrm{mM}$ Tris$\mathrm{HCl}, \mathrm{pH} 7.4$, containing $5 \mathrm{mM}$ EDTA. The mixture was added to a 1-ml Dowex X-8 column (formate form). The columns were sequentially eluted with water, $5 \mathrm{mM}$ sodium tetraborate $/ 60 \mathrm{mM}$ ammonium formate and $0.1 \mathrm{mM}$ formic acid/1 $\mathrm{M}$ ammonium formate. This sequence removed $\left[{ }^{3} \mathrm{H}\right]$-inositol, $\left[{ }^{3} \mathrm{H}\right]$-glycerophosphoinositol and $\left[{ }^{3} \mathrm{H}\right]-$ InsPs, which were extracted in the same fraction by the "batch" method (10). Radioactivity was determined by liquid scintillation spectroscopy.

In retinas from 14-day-old embryos (E14), $100 \mu \mathrm{M}$ carbachol induced an increase of $\left[{ }^{3} \mathrm{H}\right]$-phosphoinositide turnover from 374.6 \pm 41.3 to $3497.6 \pm 209.5 \mathrm{cpm} / \mathrm{mg}$ protein (Figure 1). When increasing concentrations of kainate were added to the medium, a progressive and significant decrease of carbachol-induced accumulation of $\left[{ }^{3} \mathrm{H}\right]-\mathrm{InsPs}$ 
was observed. A maximal inhibition of $\sim 50 \%$ was obtained using $1 \mu \mathrm{M}$ or higher concentrations of kainate. The estimated $\mathrm{IC}_{50}$ value for kainate was $0.2 \mu \mathrm{M}$, suggesting that this compound decreases the cholinergic stimulation of $\left[{ }^{3} \mathrm{H}\right]$-InsPs metabolism with high potency.

Although most types of AMPA/kainate receptors form channels only permeable to sodium, calcium permeable AMPA/kainate receptors appear to be present in several tissues, including the embryonic chick retina (11). In order to determine if inhibition of the muscarinic-dependent $\left[{ }^{3} \mathrm{H}\right]$-InsPs turnover was mediated by cell depolarization and influx of $\mathrm{Na}^{+}$ions, we investigated the effect of veratridine, a potent neurotoxin able to increase the permeability of voltagesensitive sodium channels, on the carbacholinduced $\left[{ }^{3} \mathrm{H}\right]-$ InsPs formation in retinas from E14 embryos (Figure 2). In these experiments, carbachol elicited an 8.4-fold stimulation of [ $\left.{ }^{3} \mathrm{H}\right]-$ InsPs turnover $(2044.5 \pm 299.9$ $\mathrm{cpm} / \mathrm{mg}$ protein, compared to basal levels of $241.2 \pm 38.0 \mathrm{cpm} / \mathrm{mg}$ protein). Veratridine, at $50 \mu \mathrm{M}$, had no significant effect on $\left[{ }^{3} \mathrm{H}\right]-$ InsPs turnover $(283.0 \pm 91.5 \mathrm{cpm} / \mathrm{mg}$ protein). When $50 \mu \mathrm{M}$ veratridine was added together with carbachol, $\sim 65 \%$ inhibition of the accumulation of $\left[{ }^{3} \mathrm{H}\right]-$ InsPs induced by muscarinic receptors was observed (861.6 \pm $113.9 \mathrm{cpm} / \mathrm{mg}$ protein). These results suggest that the influx of sodium and/or sodiuminduced depolarization of retinal cells inhibited the turnover of $\left[{ }^{3} \mathrm{H}\right]$-InsPs mediated by the activation of muscarinic receptors in this tissue.

In order to clarify further the involvement of cell depolarization in the decrease of the $\left[{ }^{3} \mathrm{H}\right]$-InsPs turnover induced by muscarinic receptors, we investigated the effect of raising the extracellular concentration of $\mathrm{KCl}$ from $5.36 \mathrm{mM}$ to $50 \mathrm{mM}$ (Figure 2). As opposed to veratridine, high extracellular $\mathrm{K}^{+}$ did not induce any significant decrease in the carbachol-stimulated $\left[{ }^{3} \mathrm{H}\right]$-InsPs levels $(2833.1 \pm 575.9 \mathrm{cpm} / \mathrm{mg}$ protein). More- over, an increase in $\left[{ }^{3} \mathrm{H}\right]-$ InsPs turnover was observed when retinas were incubated only with $50 \mathrm{mM} \mathrm{KCl}(541.8 \pm 153.3 \mathrm{cpm} / \mathrm{mg}$ protein), suggesting that $\mathrm{K}^{+}$depolarization may induce the accumulation of $\left[{ }^{3} \mathrm{H}\right]$-InsPs in developing chick retina cells.

In the present study, we have shown that low doses of kainate promoted the decrease of carbachol-induced $\left[{ }^{3} \mathrm{H}\right]$-InsPs accumulation in the chick embryonic retina. The same effect of kainate was previously observed in the hippocampus (12), prefrontal cortex (13) and mammalian retina (14). Moreover, previous data have shown that preincubation of chick embryonic retinas with kainate followed by extensive washing and stimulation with carbachol was not able to change the retinal response to carbachol (2). Taken together, these observations suggest that the inhibition by kainate of the cholinergic-dependent $\left[{ }^{3} \mathrm{H}\right]-$ InsPs accumulation may not involve the toxic effect of glutamate agonists that was previously described in the rat cerebral cortex (15) or cultured retinal cells (16).

Some of the muscarinic receptor subtypes belong to a general class of "calciummobilizing" receptor systems that operate through a common pathway. In cell lines, it has been observed that an agonist could desensitize the InsPs response to another agonist by depleting the agonist-sensitive intracellular calcium pools (17). In several tissues, including the retina, glutamate agonists induce the formation of $\operatorname{InsPs}(2,14,18)$.

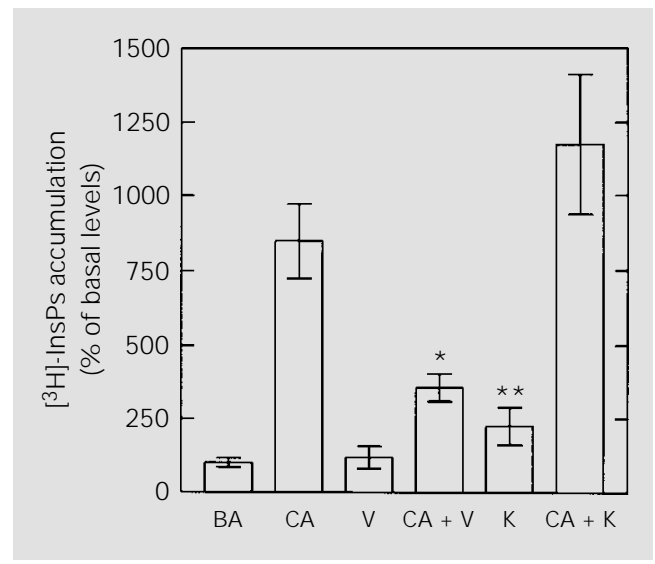

Figure 2 - Inhibition of the carbachol (CA)-induced [ $\left.{ }^{3} \mathrm{H}\right]$-InsPs accumulation by depolarizing agents in retinas of 14-day-old embryos (E14). Veratridine (V), at $50 \mu \mathrm{M}$, and $50 \mathrm{mM} \mathrm{KCl}(\mathrm{K})$ were added $10 \mathrm{~min}$ before 100 $\mu \mathrm{M}$ carbachol. Data are reported as mean \pm SEM (error bars) for 3 to 6 experiments performed in duplicate. No significant difference was observed between non-stimulated retinas and those incubated only with veratridine. $* \mathrm{P}<0.01$ vs $\mathrm{CA}$; $* * \mathrm{P}<0.05$ vs basal levels (BA) (Student t-test). 
Thus, one explanation for the decrease in the muscarinic receptor response induced by kainate would be that this agonist is able to induce the depletion of calcium stores that are necessary for the activation of phospholipase C. However, we did not observe any increase in the $\left[{ }^{3} \mathrm{H}\right]$-InsPs turnover when retinas were incubated only with kainate. In addition, we detected a maximal inhibition of the muscarinic response using $1 \mu \mathrm{M}$ kainate, a concentration that is not sufficient to induce the phosphoinositide turnover of chick retinal cells (18), suggesting that the inhibitory effect of kainate may not be related to a kainate-dependent stimulation of phosphoinositide metabolism or to a heterologous desensitization of this pathway in this tissue.

Previous studies have shown that activation of muscarinic receptors mobilizes calcium from intracellular stores but does not induce the influx of calcium through L-type voltage-sensitive channels in the retina $(3,14)$. A recent report, however, has shown that opening of L-type calcium channels by depolarization with high extracellular $\mathrm{KCl}$ or Bay K 8644 induced the formation of InsPs in chick retina cells in culture (19), suggesting that the influx of calcium through these channels induces the activation of phospholipase $\mathrm{C}$. In the present study, we show that high extracellular $\mathrm{KCl}$, but not kainate or veratridine, induces the accumulation of $\left[{ }^{3} \mathrm{H}\right]$ -
InsPs in the embryonic retina, suggesting that calcium mobilization occurs under $\mathrm{KCl}$, but not kainate or veratridine stimulation of the tissue. Moreover, since kainate stimulates the influx of $\mathrm{Na}^{+}$in chick retinal cells (20) and veratridine increases the permeability of voltage-sensitive $\mathrm{Na}^{+}$channels, our data showing that these compounds inhibit the calcium-dependent InsPs turnover induced by muscarinic receptors suggest that sodium influx may interfere with the activation of phospholipase $\mathrm{C}$ by acetylcholine in the chick embryo retina.

In contrast to kainate, high extracellular $\mathrm{K}^{+}$did not decrease the accumulation of $\left[{ }^{3} \mathrm{H}\right]-$ InsPs induced by carbachol in the chick embryo retina. Since high extracellular K ${ }^{+}$stimulates InsPs turnover in intact retinas (Figure 2 ) and retinal cells in culture (19), our results showing no inhibitory effect of $\mathrm{K}^{+}$suggest that an inhibition of retinal response to carbachol promoted by the influx of $\mathrm{Na}^{+}(20)$ may not be detected under $\mathrm{KCl}$ stimulation. Details of the $\mathrm{Na}^{+}$-dependent pathway of inhibition of $\left[{ }^{3} \mathrm{H}\right]$-InsPs accumulation are currently being investigated.

\section{Acknowledgments}

We thank Drs. M.C.F. de Mello and R. Paes de Carvalho for reviewing the manuscript.

\section{References}

1. Tobin $A B$, Willars $G B \&$ Nahorski $S R$ (1996). Regulation and desensitization of the phosphoinositidase $C$ signalling pathway. In: Uchida MK (Editor), Receptor Desensitization and $\mathrm{Ca}^{++}$Signalling. J apan Scientific Societies Press, Tokyo.

2. Calvet GA \& Ventura ALM (1995). Accumulation of ${ }^{3} \mathrm{H}$-phosphoinositides by muscarinic receptors in the developing chick retina: inhibition of carbachol-induced response mediated by glutamate receptors. J ournal of Neurochemistry, 64: 10641070.

3. Yamashita M, Yoshimoto $Y \&$ Fukuda $Y$
(1994). Muscarinic acetylcholine responses in the early embryonic chick retina. J ournal of Neurobiology, 25: 11441153.

4. Sakaki Y, Sugioka M, Fukuda Y \& Yamashita M (1997). Capacitive $\mathrm{Ca}^{2+}$ influx in the neural retina of chick embryo. J ournal of Neurobiology, 32: 62-68.

5. Sakaki Y, Fukuda Y \& Yamashita M (1996). Muscarinic and purinergic $\mathrm{Ca}^{2+}$ mobilizations in the neural retina of early embryonic chick. International J ournal of Developmental Neuroscience,14: 691-699.

6. Large $\mathrm{TH}, \mathrm{Cho} \mathrm{NJ}$, De Mello FG \& Klein
WL (1985). Molecular alteration of a muscarinic acetylcholine receptor system during synaptogenesis. J ournal of Biological Chemistry, 269: 8873-8881.

7. Large TH, Rauh J J, De Mello FG \& Klein WL (1985). Two molecular weight forms of muscarinic acetylcholine receptors in the avian central nervous system: switch in predominant form during differentiation of synapses. Proceedings of the $\mathrm{Na}$ tional Academy of Sciences, USA, 82: 8785-8789.

8. Cho NJ \& Klein WL (1988). Muscarinic acetylcholine receptors from avian retina 
and heart undergo different patterns of molecular maturation. J ournal of Neurochemistry, 50: 1403-1411.

9. Lowry $\mathrm{OH}$, Rosebrough $\mathrm{HJ}$, Farr $\mathrm{AL} \&$ Randall RJ (1951). Protein measurement with the Folin phenol reagent. J ournal of Biological Chemistry, 193: 265-275.

10. Berridge MJ, Dawson RM, Downes CP, Heslop J P \& Invine RF (1983). Changes in the levels of inositol phosphates after agonist-dependent hydrolysis of membrane phosphoinositides. Biochemical J ournal, 212: 473-482.

11. Allcorn S, Catsicas M \& Mobbs P (1996). Developmental expression and self-regulation of $\mathrm{Ca}^{2+}$ entry via AMPA/KA receptors in the embryonic chick retina. European J ournal of Neuroscience, 8: 24992510.

12. Baudry M, Evans J \& Lynch G (1986). Excitatory amino acids inhibit stimulation of phosphatidylinositol metabolism by aminergic agonists in hippocampus. Na- ture, 319: 329-331.

13. Noble EP, Sincini E, Bergmann D \& Ten Bruggencate G (1989). Excitatory amino acids inhibit stimulated phosphoinositide hydrolysis in the rat prefrontal cortex. Life Sciences, 44: 19-26.

14. Osborne NN \& Ghazi H (1990). Agoniststimulated inositol phospholipid hydrolysis in the mammalian retina. In: Osborne NN \& Chader J (Editors), Progress in Retinal Research. Pergamon Press, Oxford.

15. Challis RAJ, Mistry R, Gray DW \& Nahorski SR (1994). Modulation of muscarinic cholinoceptor-stimulated inositol 1,4,5-triphosphate accumulation by $\mathrm{N}$ methyl-D-aspartate in neonatal rat cerebral cortex. Neuropharmacology, 33: 1525.

16. Ferreira IL, Duarte $\mathrm{CB} \&$ \& Canvalho AP (1996). $\mathrm{Ca}^{2+}$ influx through glutamate receptor-associated channels in retina cells correlates with neuronal cell death. European J ournal of Pharmacology, 302: 153-
162.

17. Willars GB \& Nahorski SB (1995). Heterologous desensitization of both phosphoinositide and $\mathrm{Ca}^{2+}$ signaling in $\mathrm{SH}-\mathrm{SY} 5 \mathrm{Y}$ neuroblastoma cells: A role for intracellular $\mathrm{Ca}^{2+}$ store depletion? Molecular Pharmacology, 47: 509-516.

18. Reis RAM, Kubrusly RCC, De Mello MCF $\&$ De Mello FG (1995). Transient coupling of NMDA receptor with ip 3 production in cultured cells of the avian retina. Neurochemistry International, 26: 375-380.

19. Gan J \& luvone PM (1997). Depolarization and activation of dihydropyridine-sensitive $\mathrm{Ca}^{2+}$ channels stimulate inositol phosphate accumulation in photoreceptor-enriched chick retinal cell cultures. J ournal of Neurochemistry, 68: 2300-2307.

20. Agostinho $P$, Duarte $C B \&$ Oliveira $C R$ (1996). Activity of ionotropic glutamate receptors in retinal cells: effect of ascorbate/ $\mathrm{Fe}^{2+}$-induced oxidative stress. J ournal of Neurochemistry, 67: 1153-1163. 